the Romans and during the last hundred years. How well the Romans worked can be seen from the remains of causeways and sewers now and again brought to light during excavations in the City. With the departure of the Romans went the art of road-making, and for century after century the citizens accepted with extraordinary complacency conditions which would not be tolerated in any city to-day. As a rule, the roads were unfit for wheeled traffic, the sidewalks were of gravel and dirt, the rain spouts projected over the pavements and such sewers as there were were connected ineffectively with gutters full of holes. Complaints were made over and over again, and though surveyors and paviors were appointed, things were seldom satisfactory. Even in the days of Wren and Newton, Ludgate Hill and Fleet Street drained into the mudfilled Fleet River, which had long ceased to be navigable and had become a nuisance. Westminster was every bit as bad as London, and in 1742 Lord Tyrconnel in the House of Lords said: "The filth of some parts of Westminster and the inequality and ruggedness of others, cannot but in the eyes of the foreigners disgrace our nation, and incline them to imagine us a people, not only without delicacy, but without government, a herd of barbarians, or a colony of hottentots". Improvements were effected from time to time, it is true, but it was only during last century that real progress was made.

\section{Archæological Exhibitions at the British Museum}

AT the recent annual meeting of the subscribers to the British School of Archæology in Athens, reference was made in the usual review of the School's work to the votive house, or temple, models which had been discovered in the course of the excavation of the Heræum at Perachora, near Corinth. From incomplete fragments a complete model has been reconstructed, which is now on view in the British Museum. The model is about a foot in height, and gives for the first time an idea in detail of the character of the house in the Egean during the Geometric period. The models are dated at about the middle of the eighth century B.c. The most striking feature of the construction is the apse, which Sir Arthur Evans has suggested may have arisen from the earliest form of building, in which the back wall was formed by hollowing out a cliffface. The door of the building has antæ with columns, and above it are three small windows.

ON March 7 an exhibition will open of the finds of the joint expedition of the British Museum and the British School of Archæology in Iraq under the leadership of Mr. M. E. L. Mallowan, at Arpachiyah, near Nineveh, in northern Iraq, during the season 1932-33. This material should have been on view last summer, but its dispatch from Iraq was delayed by action of the Government in settling the allocation of the material found by the expedition. The finds now shown will illustrate the cultures of the ten successive prehistoric settlements discovered at Arpachiyah. This sequence, in which the occurrence and development of the painted pottery can be followed from the earliest settlement, and the evidence of early relations with prehistoric India, Baluchistan, southern Mesopotamia and Crete, make Arpachiyah one of the most important sites known for the early prehistory of Iraq. Unfortunately, partly owing to lack of funds, excavations have been suspended.

\section{Recent Acquisitions at the Natural History Museum}

By the will of the late Lieut.-Col. C. G. Nurse, the Trustees of the British Museum (Natural History) have received a bequest of 3,000 Indian insects mostly obtained at Quetta, Deesa and Jubbulpore, where Col. Nurse served with the Indian Army. Col. Nurse was one of the small band of naturalists among military officers who devoted their leisure to the study of entomology, and was an enthusiastic collector of Hymenoptera, forming a large and valuable collection which he presented to the Museum a few years ago. The present bequest comprises the remainder of his Indian insects and includes about 1,450 Diptera (two winged flies), 1,300 butterflies, 130 dragon-flies and some others; of these the most valuable are the Diptera. The collection is especially rich in species of the family Bombyliidæ, most of which are parasitic in the larval state on bees or wasps. Col. Nurse discovered and described fourteen species of this family which were new to science, and types of these are in the collection, as well as specimens of a number of other flies which were not previously represented in the Museum. Some interesting butterflies and other insects from Aden are included.

THE Department of Botany of the Museum has been presented with sixty-three bundles of plants by the Hancock Museum, Newcastle-upon-Tyne. These plants were presumably presented to the Newcastle Museum by William Robertson, who bought them at the sale in 1842 of A. B. Lambert's herbarium, which was one of the largest ever in private hands. The specimens are of historical interest as they presumably include the remainder of the herbarium of P. S. Pallas, a Russian botanist who died in 1811. Pallas's plants were acquired by Lambert, who picked out one set for himself and one for Sir Joseph Banks. Banks's set went to the Museum in 1827, and Robert Brown purchased Lambert's own set at the sale. Judging from the specimens so far examined, the present acquisition represents the remainder of the herbarium. Much will probably be duplicate material but a good deal of information can be obtained from the original wrappers in which the plants still are. Further, it is probable that some plants figured by Pallas, which have been missing, will be brought to light. The bundles also contain about 500 plants collected by the Rev. E. D. Clarke, who visited Pallas in the Crimea in 1800. The plants were named by Pallas. Among the purchases are 800 flowering plants from Spain and Morocco (Sennen), 1,500 from North America (Marcus E. Jones) and 900 from Eastern Greece, Ægean Islands, etc. (K. H. Rechinger). 